\title{
PENGARUH LOVE OF MONEY DAN RELIGIOSITAS TERHADAP PERILAKU ETIS (STUDI PADA KARYAWAN MUSLIM DI SEKTOR PERBANKAN)
}

\author{
THE EFFECT OF LOVE OF MONEY AND RELIGIOSITY ON ETHICAL BEHAVIOR \\ (STUDY ON MUSLIM EMPLOYEES IN BANKING SECTOR)
}

\author{
Shabrina Dwi Nova*) dan Fanny Martdianty ${ }^{* 1}$ \\ *) Fakultas Ekonomi dan Bisnis, Universitas Indonesia \\ Jl. Prof. DR. Sumitro Djojohadikusumo, Kukusan, Kecamatan Beji, Kota Depok, Jawa Barat 16424
}

\begin{abstract}
This study aimed to examine the conceptual model covering the variable of loveof-money, religiosity, organizational commitment, salary satisfaction, and ethical behavior on the samples of Muslim employees in the banking sector. This study used a quantitative design by collecting data from 637 respondents based on purposive sampling. The data processing was conducted using Structural Equation Modeling (SEM) method, with LISREL 8.8 software. This study found that love-of-money directly and negatively affected ethical behavior, while religiosity had a significant and positive effect on ethical behavior. Unlike the love-of-money variable that only directly and significantly affected ethical behavior, this study proved the indirect effect of religiosity on ethical behavior through salary satisfaction and organizational commitment.
\end{abstract}

Keywords: love of money, religiosity, ethical behavior, pay satisfaction, organizational commitment

\begin{abstract}
Abstrak: Penelitian ini bertujuan menguji model konseptual yang melibatkan variabel love of money, religiositas, komitmen organisasional, kepuasan gaji dan perilaku etis pada sampel karyawan muslim di sektor perbankan. Studi ini menggunakan desain kuantitatif dengan melakukan pengambilan data dengan teknik purposive sampling kepada 637 responden dengan karyawan muslim di sektor perbankan. Pengolahan data dilakukan dengan menggunakan metode Structural Equation Model (SEM) dengan bantuan perangkat lunak LISREL 8.8. Penelitian ini menemukan bahwa love of money secara langsung berpengaruh negatif terhadap perilaku etis, sedangkan religiositas secara signifikan berpengaruh positif terhadap perilaku etis. Berbeda dengan variabel love of money yang hanya memiliki pengaruh langsung signifikan terhadap perilaku etis karyawan; pada penelitian ini terbukti adanya pengaruh tidak langsung religiositas terhadap perilaku etis melalui kepuasan gaji dan komitmen organisasional.
\end{abstract}

Kata kunci: love of money, religiositas, perilaku etis, kepuasan gaji, komitmen organisasional

\footnotetext{
${ }^{1}$ Corresponding author:

Email: fanny.martdianty@ui.ac.id
} 


\section{PENDAHULUAN}

Industri perbankan merupakan salah satu industri penyedia jasa perantara keuangan tertua di dunia (Joshi dan Goyal, 2011) yang saat ini keberadaannya semakin dibutuhkan oleh masyarakat. Tanggung jawab perbankan tidak hanya kepada nasabah, namun juga kepada pemerintah, pemegang saham, karyawan, dan masyarakat (Herzog, 2019; Paulet et al. 2015). Memahami besarnya tanggung jawab yang dimiliki, bank membutuhkan standar etik. Standar etik dibutuhkan agar seluruh pihak yang terlibat dalam menjalankan bisnis perbankan dapat mengetahui apa yang diekspektasikan dari mereka, dapat membantu karyawan terhindar dari tekanan maupun godaan tindakan yang tidak sesuai dengan etika yang dapat merugikan perusahaan, dan meningkatkan reputasi perusahaan sehingga dapat memastikan kesuksesan jangka panjang (Ogbari et al. 2016) serta berpengaruh juga terhadap kinerja pegawai (Yasin et al. 2019). Mengingat pentingnya etika pada perbankan, berbagai bank telah membentuk standar etik atau yang sering disebut kode etik (code of conduct) yang berisikan komitmen kepada pihak yang berkepentingan, sekaligus sebagai perwujudan dari etika bisnis dan etika kerja yang ada pada masing-masing bank.

Walaupun upaya untuk membentuk lingkungan kerja yang etis telah dilakukan, pada kenyataannya perilaku yang tidak sesuai dengan etika bisnis masih banyak terjadi di perbankan, misalnya fraud atau penipuan. Hal ini dibuktikan oleh studi yang dilakukan oleh Association of Certified Fraud Examiner, suatu organisasi anti penipuan terbesar di dunia yang menjadi penyedia utama pelatihan dan pendidikan anti penipuan. Berdasarkan tiga laporan berbeda yang diterbitkan oleh Association of Certified Fraud Examiners pada tahun 2014, 2016, 2018 menunjukan bahwa perbankan merupakan sektor dengan tingkat penipuan tertinggi di dunia dibandingkan dengan sektor-sektor lainnya. Bukan hanya di dunia, fenomena perilaku tidak etis juga terjadi pada perbankan di Indonesia. Menurut siaran pers Otoritas Jasa Keuangan (OJK) pada November 2016, diketahui bahwa tindak pidana perbankan pada tahun 2014 hingga triwulan ketiga 2016 mencapai 108 kasus, yang terjadi pada semua jenis bank, baik perbankan konvensional maupun perbankan syariah. Di dalam siaran pers tersebut juga dijelaskan bahwa berdasarkan statistik penanganan tindak pidana perbankan yang ditangani oleh OJK, jenis kasus tindak pidana perbankan yang terjadi pada tahun 2014 hingga triwulan ketiga tahun 2016 adalah kasus kredit (55\%), rekayasa pencatatan $(21 \%)$, penggelapan dana $(15 \%)$, transfer dana (5\%), dan pengadaan aset (4\%) (Otoritas Jasa Keuangan, 2016).

Perilaku tidak etis yang dilakukan oleh karyawan dapat memberikan dampak material maupun tidak material yang merugikan perusahaan. Dampak material dapat berupa kerugian finansial, sedangkan dampak non material antara lain dapat merusak reputasi perusahaan, merusak hubungan dengan konsumen maupun pemangku kepentingan lainnya, serta berdampak negatif pada keberlangsungan perusahaan (Singh dan Twalo, 2015). Melihat dampaknya yang besar, perilaku tidak etis menjadi permasalahan yang perlu menjadi perhatian. Beberapa peneliti telah mencoba meneliti akar permasalahan perilaku tidak etis dari berbagai perspektif. Beberapa peneliti menemukan bahwa love of money, religiositas, kepuasan gaji, dan komitmen organisasional memiliki pengaruh terhadap perilaku etis seseorang (Singhapakdi et al. 2013; Tang dan Chiu, 2003; Tang et al. 2018).

Love of money merupakan salah satu pengukuran yang muncul untuk mengetahui seberapa penting uang bagi seseorang. Love of money didefinisikan sebagai salah satu sikap seseorang terhadap uang yang didalamnya berisi komponen afektif (affective), tingkah laku (behavior) dan kognitif (cognitive) (Tang et al. 2018). Pada penelitian-penelitian sebelumnya, ditemukan bahwa love of money memiliki pengaruh terhadap variabel-variabel lainnya seperti pengaruh negatif terhadap perilaku etis (Singhapakdi et al. 2013; Tang et al. 2018) serta kepuasan gaji (Tang dan Chiu, 2003).

Selain love of money, faktor lainnya yang dipercaya mempengaruhi perilaku etis seseorang adalah religiositas. de Soto et al. (2018) menemukan bahwa seseorang dengan tingkat religiositas yang tinggi, akan cenderung berperilaku lebih etis. Beberapa peneliti lain juga menemukan bahwa religiositas memiliki pengaruh positif pada perilaku etis seseorang (Arli, 2017; Uyar et al. 2015; Voegel dan Pearson, 2016). Pengaruh positif religiositas terhadap etis mengindikasikan apabila tingkat religiositas seseorang meningkat, maka kecenderungan untuk berperilaku etis pun meningkat.

Pada penelitian-penelitian sebelumnya, ditemukan bahwa religiositas memiliki pengaruh terhadap variabel-variabel lainnya. Misalnya pengaruh religioisitas terhadap perilaku etis (de Soto et al. 2018; 
Singhapakdi et al. 2013). Selain itu beberapa studi juga telah membuktikan kaitan antara religiositas terhadap kepuasan gaji (Amaliah et al. 2015) serta terhadap komitmen organisasional (e.g. Farrukh et al, 2016; Wening dan Choerudin, 2015). Komitmen organisasional sendiri juga memiliki pengaruh terhadap perilaku etis seseorang (Posey et al. 2015).

Berdasarkan pemaparan penelitian-penelitian sebelumnya, dapat dilihat bahwa penelitian mengenai faktor-faktor yang mempengaruhi perilaku etis terus berkembang. Akan tetapi, peneliti menemukan bahwa literatur yang membahas mengenai akar permasalahan etis di perbankan masih terbatas. Padahal seperti yang sudah disinggung sebelumnya, perbankan merupakan industri dengan tingkat perilaku tidak etis berupa penipuan tertinggi di dunia dalam beberapa periode. Penelitian mengenai akar permasalahan perilaku etis di perbankan juga menjadi penting mengingat peran dan tanggung jawab perbankan kepada masyarakat cukup besar sehingga dibutuhkan informasi untuk mengevaluasi masalah perilaku etis yang terjadi. Penelitian ini juga menggunakan konteks religiositas yang lebih dikaitkan dengan nilai-nilai dalam Islam berbeda daripada beberapa penelitian sebelumnya (Singhapakdi et al. 2013) yang lebih berfokus pada religiositas secara umum, tanpa mengaitkan dengan nilai-nilai yang terkandung pada satu agama tertentu. Penelitian ini diharapkan dapat menambah kontribusi pada topik penelitian yang berkaitan dengan etika dan religiositas, terutama di sektor perbankan serta konteks negara yang didominasi oleh penduduk muslim lainnya. Selain itu, penelitian ini diharapkan dapat menjadi referensi bagi para manajer SDM di sektor perbankan terkait akar permasalahan dari perilaku tidak etis serta dapat memberikan saran dalam peningkatan perilaku etis karyawan berdasarkan temuan penelitian.

Penelitian ini bertujuan untuk menguji secara empiris mengenai pengaruh langsung faktor yang berkontribusi terhadap perilaku etis yang diwakili oleh variabel love of money dan religiositas, serta menguji pengaruh tidak langsungkeduafaktortersebutmelaluivariabelkepuasan gaji dan komitmen. Variabel love of money merupakan variabel yang diyakini banyak studi merupakan variabel yang menjadi akar dari banyak skandal organisasi (root of evil), sedangkan variabel religiositas merupakan faktor yang secara konseptual dipercaya sebagai faktor yang mendukung dalam pengambilan keputusan etis seorang individu (Singhapakdi et al. 2013).

\section{METODE}

Penelitian ini menggunakan desain penelitian kuantitatif dengan metode pengambilan data survey dengan purposive sampling yang dilakukan dari bulan Maret-Mei 2019. Peneliti mengumpulkan data primer yang diperoleh melalui kuesioner yang didesain secara daring melalui google form dan disebarkan melalui berbagai media. Responden pada penelitian ini adalah karyawan muslim yang telah bekerja di bank, baik bank konvensional atau pun bank syariah selama minimal tiga tahun. Karyawan muslim dipilih karena peneliti ingin melakukan pengujian terhadap konstruk religioisitas yang lebih spesifik sesuai dengan nilai ajaran Islam serta menjadi penduduk mayoritas di Indonesia. Peneliti juga melihat adanya peluang untuk menjemput bola dengan berusaha mendapatkan responden dari salah satu kantor cabang pembantu (KCP) bank syariah yang ada di sekitar kampus peneliti. Peneliti mendapatkan izin untuk menyebarkan kuesioner dan diminta untuk memberikan kuesioner tersebut secara cetak. Dari 10 kuesioner dalam bentuk cetak tersebut, hanya 4 responden yang merespon dan dapat diproses. Tidak ada perbedaan isi antara kuesioner yang dikumpulkan secara daring atau pun dalam versi hardcopy. Peneliti juga menambahkan pertanyaan konfirmasi dalam kuesioner yang dicetak tersebut bahwa responden belum pernah mengisi kuesioner yang sama dalam versi google form. Sebanyak total 723 responden terjaring selama periode survei, setelah dilakukan data cleaning, 637 responden dilanjutkan dalam proses analisis data. Dari jumlah responden final, 317 responden berasal dari kantor regional bank di wilayah Jabodetabek, sedangkan 320 responden lainnya berasal dari kantor regional bank di luar Jabodetabek.

Kuesioner menggnakan skala likert 7-poin dengan keterangan 1 yang berarti sangat tidak setuju sampai 7 yang berarti sangat setuju. Kuesioner akan diisi langsung oleh responden (self-administered questionnare) menggunakan kuesioner daring dan kuesioner hardcopy. Model penelitian ini adalah hasil modifikasi dari model penelitian sebelumnya yang dilakukan oleh Tang dan Chiu (2003) dan Singhapakdi et al. (2013). Alat ukur yang digunakan dalam penelitian ini adalah alat ukur love of money (Tang dan Chiu 2003); religiositas islam (Alam et al. 2011; Khraim, 2010); kepuasan gaji (Heneman dan Schwab, 1985), komitmen organisasional (Mowday et al. 1979); serta perilaku etis (Fraedrich, 1993). 
Analisis data dilakukan dengan menggunakan structural equation model dengan Lisrel. Pada metode structural equation model, terdapat dua model, yaitu model pengukuran dan model struktural (Wijanto, 2008). Analisis model pengukuran digunakan untuk mengevaluasi hubungan antara indikator-indikator variabel dengan konstruknya (Hair, et al. 2014). Hasil akhirmodelpengukuran diperoleh melaluiuji kecocokan seluruh model, analisis validitas model, dan analisis reliabilitas model (Wijanto, 2008). Analisis model struktural digunakan untuk menjelaskan hubunganhubungan yang ada di antara variabel-variabel laten (Wijanto, 2008). Secara umum, uji kecocokan model struktural terdiri dari dua tahap yaitu uji kecocokan model struktural dan analisis hubungan kausal.

Model penelitian dapat dilihat pada Gambar 1. Model penelitian ini adalah hasil modifikasi dari model penelitian sebelumnya yang dilakukan oleh Tang dan Chiu (2003) dan Singhapakdi et al. (2013). Pada penelitian ini, variabel yang digunakan berdasarkan penelitian Tang dan Chiu (2003) antara lain, love of money, kepuasan gaji, komitmen organisasional, dan perilaku etis, sedangkan variabel yang digunakan berdasarkan penelitian Singhapakdi et al. (2013), yaitu religiositas, love of money, dan perilaku etis. Sehingga, pada penelitian ini variabel yang digunakan sebanyak lima variabel, yaitu love of money, religiositas, kepuasan gaji, komitmen organisasional, dan perilaku etis. Berikut ini adalah hipotesis yang diajukan dalam penelitian ini:

Beberapa studi telah membuktikan ada keterkaitan antara love of money terhadap kecendrungan berperilaku etis seseorang. Singhapakdi et al. (2013) menemukan bahwa ketika tingkat love of money seseorang tinggi, maka manajer tersebut cenderung berperilaku dan memiliki niat yang kurang sesuai dengan etika. Hasil tersebut juga mendukung temuan dari Tang dan Chen (2008) dan Tang et al. (2018), Selain itu, love of money juga memiliki pengaruh negatif terhadap kepuasan gaji, artinya ketika individu memiliki kecintaan pada uang lebih tinggi, maka individu tersebut punya kecendrungan untuk tidak puas terhadap gaji yang diterima (Tang dan Chiu, 2003). Berdasarkan kajian literatur tersebut, maka peneliti mengajukan hipotesis berikut:
H1 : Love of money memiliki pengaruh negatif terhadap perilaku etis karyawan muslim di sektor perbankan.

$\mathrm{H} 2$ : Love of money memiliki pengaruh negatif terhadap kepuasan gaji karyawan muslim di sektor perbankan.

Weaver dan Agle (2002) mengatakan bahwa setiap peran dari religiositas dieskpektasikan memiliki peranan terhadap satu atau lebih proses etika, mulai dari kesadaran akan etika (awareness), pertimbangan (judgment), intensi atau niat (intention), hingga menjadi perilaku (behavior) dalam beretika. Selain itu, beberapa penelitian juga membuktikan keterkaitan antara religiositas terhadap perilaku etis (de Soto et al. 2018; Purnamasari dan Amaliah, 2015) ditemukan bahwa seseorang dengan tingkat religiositas yang tinggi akan cenderung memiliki tingkat perilaku etis yang lebih tinggi. Religiositas juga memiliki keterkaitan dengan kepuasan gaji. Amaliah et al. (2015) menemukan bahwa religiositas Islam memiliki pengaruh terhadap kepuasan atas kerja menurut Islam yang didalamnya termasuk kepuasan gaji (material), moral, dan spiritual. Seseorang yang memiliki tingkat religisotas yang tinggi juga dindikasikan sebagai individu yang memiliki komitmen lebih tinggi, studi dari Farrukh et al. (2016) yang menemukan bahwa secara keseluruhan religiositas memiliki pengaruh positif terhadap komitmen organisasional. Berdasarkan hal tersebut, maka peneliti mengajukan hipotesis berikut ini:

H3 : Religiositas memiliki pengaruh positif terhadap perilaku etis karyawan muslim di sektor perbankan.

H4 : Religiositas memiliki pengaruh positif terhadap kepuasan gaji karyawan muslim di sektor perbankan.

H5 : Religiositas memiliki pengaruh positif terhadap komitmen organisasional karyawan muslim di sektor perbankan

Terkait dengan variabel kepuasan gaji, beberapa studi telah membuktikan adanya kaitan antara kepuasan gaji terhadap komitmen organisasional (Kee et al. 2016) dan juga perilaku etis karyawan (Sardžoska dan Tang, 2015), penelitian tersebut menemukan bahwa karyawan yang puas terhadap gaji yang diterima, memiliki kecendrungan untuk lebih berkomitmen. Karyawan yang berkomitmen juga memiliki kecendrungan lebih 
tinggi untuk berperilaku etis ketika bekerja (Posey et al. 2015). Berdasarkan kajian literatur tersebut, maka hipotesis berikut ini diajukan:

H6 : Kepuasan gaji memiliki pengaruh positif terhadap komitmen organisasional karyawan muslim di sektor perbankan.

H7 : Kepuasan gaji memiliki pengaruh positif terhadap perilaku etis pada karyawan muslim di sektor perbankan.

H8 : Komitmen organisasional memiliki pengaruh positif terhadap perilaku etis pada karyawan muslim di sektor perbankan.

Selain menguji pengaruh langsung peneliti juga melakukan pengujian pengaruh tidak langsung beberapa variabel terkait terutama love of money dan religiositas. Berikut ini adalah hipotesisnya:

H9 : Pengaruh love of money terhadap perilaku etis yang dimediasi oleh kepuasan gaji dan komitmen organisasional

H10 : Pengaruh religiositas terhadap komitmen organisasional yang dimediasi oleh kepuasan gaji

H11 : Pengaruh religiositas terhadap perilaku etis yang dimediasi oleh kepuasan gaji dan komitmen organisasional

\section{HASIL}

Tabel 1 menjelaskan hasil uji pengukuran model, yang terdiri dari uji reliabilitas, uji validitas, dan uji kecocokan model. Dari 56 indikator pernyataan, terdapat 2 indikator yaitu R3 dan PE1 yang tidak valid dikarenakan SLF kurang dari 0,50 (Igbaria et al. 1998 dalam Wijanto, 2008), walaupun t-value lebih besar dari 1,96 (Rigdon dan Ferguson,1991 dalam Wijanto, 2008). Dua indikator tersebut kemudian dikeluarkan dari model. Selain itu, variabel LOM dan R memiliki nilai variance extracted (VE) di bawah ketentuan berdasarkan Hair et al. (1998) dalam Wijanto (2008), yaitu 0,5. Akan tetapi, berdasarkan kriteria Fornell dan Larcker (1981), kondisi ini diperbolehkan, dikarenakan nilai construct reliability (CR) pada variabel LOM dan $\mathrm{R}$ menunjukkan hasil di atas 0,6. Dengan demikian, seluruh variabel dapat dikatakan reliabel.

Model juga perlu diuji kecocokannya menggunakan goodness of fit (GOF). Ada berbagai indeks yang dapat menunjukkan kecocokan suatu model, akan tetapi menurut Hair et al. (2010) yang diperlukan untuk melakukan uji kecocokan hanya 3 hingga 4 indeks yang setidaknya terdiri dari pengukuran kecocokan absolut dan pengukuran kecocokan inkremental. Pada pengukuran kecocokan absolut, peneliti menggunakan indeks GFI, RMR, SRMR, dan RMSEA, sedangkan pada pengukuran kecocokan inkremental indeks yang digunakan adalah NNFI, NFI, AGFI, RFI, IFI, dan CFI. Berdasarkan Tabel 1, diketahui bahwa hampir seluruh indeks pada pengukuran kecocokan inkremental masuk ke dalam kriteria good fit, hanya AGFI saja yang masih masuk dalam kategori marginal fit, sedangkan pada pengukuran kecocokan absolut, hanya nilai $\operatorname{GFI}(0,83)$ dan RMSEA $(0,05)$ yang telah memenuhi nilai marginal fit, sedangkan lainnya masuk ke dalam kategori poor fit. Akan tetapi, berdasarkan aturan Hair et al. (2010), dapat dikatakan model pengukuran sudah fit, dikarenakan indeks pada masing-masing pengukuran sudah ada yang mencapai minimal marginal fit.

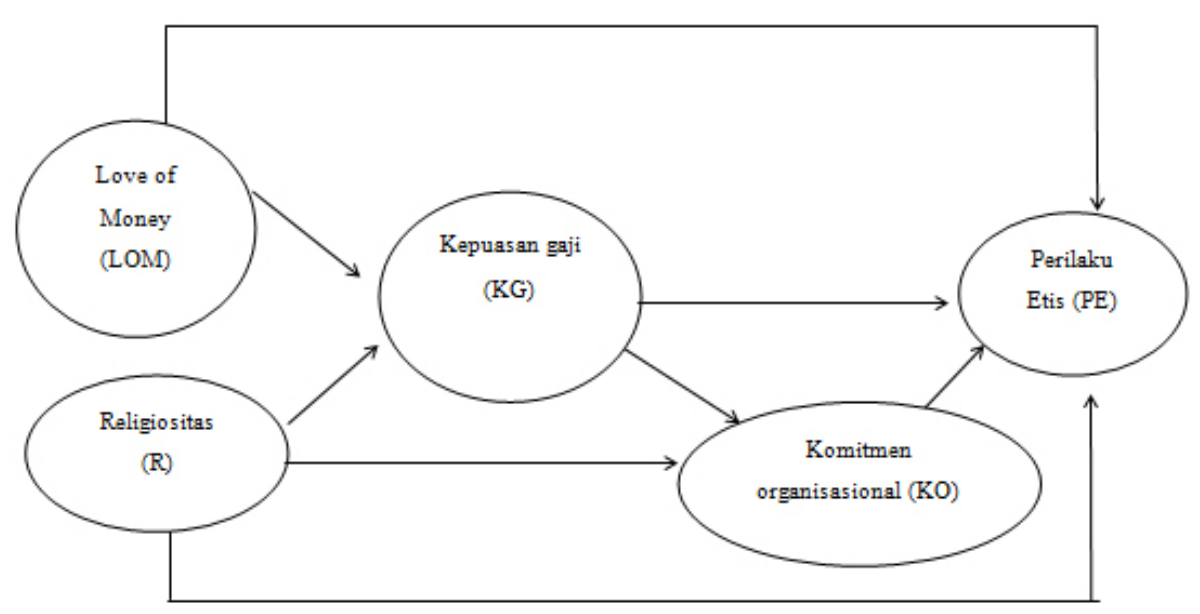

Gambar 1. Model penelitian 
Tabel 1. Hasil model pengukuran

\begin{tabular}{|c|c|c|c|c|c|c|}
\hline Indikator-Indikator variabel & Nilai- $\mathrm{t} \geq 1,96$ & SLF $\geq 0,5$ & Eror & $\mathrm{CR} \geq 0,7$ & $\mathrm{VE} \geq 50 \%$ & Kesimpulan \\
\hline Love of Money (LOM) & & & & 0,93 & $44 \%$ & Reliabel** \\
\hline LOM1 & 15,59 & 0,59 & & & & Valid \\
\hline LOM2 & 17,87 & 0,66 & & & & Valid \\
\hline LOM3 & 13,31 & 0,52 & & & & Valid \\
\hline LOM4 & 14,37 & 0,56 & & & & Valid \\
\hline LOM5 & 18,58 & 0,68 & & & & Valid \\
\hline LOM6 & 19,05 & 0,69 & & & & Valid \\
\hline LOM7 & 19,83 & 0,72 & & & & Valid \\
\hline LOM8 & 19,09 & 0,70 & & & & Valid \\
\hline LOM9 & 16,10 & 0,61 & & & & Valid \\
\hline LOM10 & 21,66 & 0,76 & & & & Valid \\
\hline LOM11 & 21,43 & 0,76 & & & & Valid \\
\hline LOM12 & 22,25 & 0,78 & & & & Valid \\
\hline LOM13 & 21,94 & 0,77 & & & & Valid \\
\hline LOM14 & 16,23 & 0,61 & & & & Valid \\
\hline LOM15 & 19,72 & 0,71 & & & & Valid \\
\hline LOM16 & 16,60 & 0,63 & & & & Valid \\
\hline LOM17 & 21,45 & 0,76 & & & & Valid \\
\hline Religiositas (R) & & & & 0,87 & $42 \%$ & Reliabel** \\
\hline R1 & 19,78 & 0,72 & & & & Valid \\
\hline R2 & 13,09 & 0,52 & & & & Valid \\
\hline R3 & 10,95 & 0,44 & & & & Tidak Valid \\
\hline R4 & 17,87 & 0,66 & & & & Valid \\
\hline R5 & 22,19 & 0,78 & & & & Valid \\
\hline R6 & 17,14 & 0,64 & & & & Valid \\
\hline R7 & 19,54 & 0,71 & & & & Valid \\
\hline R8 & 19,29 & 0,70 & & & & Valid \\
\hline R9 & 15,85 & 0,61 & & & & Valid \\
\hline Kepuasan gaji (KG) & & & & 0,96 & $61 \%$ & Reliabel \\
\hline KG1 & 24,95 & 0,82 & & & & Valid \\
\hline KG2 & 25,23 & 0,82 & & & & Valid \\
\hline KG3 & 24,17 & 0,80 & & & & Valid \\
\hline KG4 & 27,24 & 0,87 & & & & Valid \\
\hline KG5 & 27,06 & 0,86 & & & & Valid \\
\hline KG6 & 28,87 & 0,90 & & & & Valid \\
\hline KG7 & 23,88 & 0,80 & & & & Valid \\
\hline KG8 & 26,73 & 0,86 & & & & Valid \\
\hline KG9 & 29,00 & 0,90 & & & & Valid \\
\hline KG10 & 22,66 & 0,77 & & & & Valid \\
\hline KG11 & 14,29 & 0,54 & & & & Valid \\
\hline KG12 & 17,57 & 0,63 & & & & Valid \\
\hline KG13 & 18,40 & 0,66 & & & & Valid \\
\hline KG14 & 20,72 & 0,72 & & & & Valid \\
\hline KG15 & 19,67 & 0,69 & & & & Valid \\
\hline
\end{tabular}


Tabel 1. Hasil model pengukuran (Lanjutan)

\begin{tabular}{|c|c|c|c|c|c|c|}
\hline Indikator-Indikator variabel & Nilai-t $\geq 1,96$ & $\mathrm{SLF} \geq 0,5$ & Eror & $\mathrm{CR} \geq 0,7$ & $\mathrm{VE} \geq 50 \%$ & Kesimpulan \\
\hline Komitmen Organisasional(KO) & & & & 0,95 & $67 \%$ & Reliabel \\
\hline KO1 & 22,62 & 0,77 & & & & Valid \\
\hline $\mathrm{KO} 2$ & 26,24 & 0,85 & & & & Valid \\
\hline $\mathrm{KO} 3$ & 20,11 & 0,70 & & & & Valid \\
\hline KO4 & 26,71 & 0,86 & & & & Valid \\
\hline KO5 & 26,84 & 0,86 & & & & Valid \\
\hline KO6 & 26,45 & 0,85 & & & & Valid \\
\hline KO7 & 25,37 & 0,83 & & & & Valid \\
\hline KO8 & 25,43 & 0,83 & & & & Valid \\
\hline KO9 & 23,36 & 0,79 & & & & Valid \\
\hline Perilaku Etis (PE) & & & & 0,86 & $53 \%$ & Reliabel \\
\hline PE1 & 5,49 & 0,22 & & & & Tidak Valid \\
\hline PE2 & 14,62 & 0,55 & & & & Valid \\
\hline PE3 & 19,60 & 0,70 & & & & Valid \\
\hline PE4 & 28,37 & 0,92 & & & & Valid \\
\hline PE5 & 25,86 & 0,85 & & & & Valid \\
\hline PE6 & 25,72 & 0,87 & & & & Valid \\
\hline
\end{tabular}

Hasil kecocokan model : GFI $(\geq 0,90)=0,83$ (marginal fit); RMR $(\leq 0,08)=0,12$ (poor fit); $\operatorname{SRMR}(\leq 0,05)=0,058$ (poor fit); RMSEA $(<0,05)=0,050$ (marginal fit); NNFI $(\geq 0,90)=0,97$ (good fit) ; NFI $(\geq 0,90)=0,96$ (good fit) ; AGFI $(\geq 0,90)$ $=0,81$ (marginal fit); RFI $(\geq 0,90)=0,95$ (good fit); IFI $(\geq 0,90)=0,97$ (good fit); CFI $(\geq 0,90)=0,97$ (good fit)

** Berdasarkan Fornell dan Larcker (1981)

Berdasarkan Gambar 2, diketahui bahwa terdapat enam pengaruh langsung yang signifikan karena nilainya $\geq 1,645$ atau $\leq-1,645$ dan dua pengaruh langsung yang tidak signifikan dikarenakan t-value-nya tidak memenuhi kriteria yang ditetapkan. Dua pengaruh yang tidak signifikan, yaitu love of money terhadap kepuasan gaji (LOM $\rightarrow \mathrm{KG})$ dan kepuasan gaji terhadap perilaku etis $(\mathrm{KG} \rightarrow \mathrm{PE})$.

Berdasarkan Gambar 2, terdapat pengaruh negatif love of money terhadap perilaku etis (LOM $\rightarrow \mathrm{PE})$. Selain pengaruh negatif yang diberikan love of money terhadap perilaku etis, terdapat pula pengaruh yang bersifat positif, yaitu pengaruh kepuasan gaji terhadap komitmen organisasional $(\mathrm{KG} \rightarrow \mathrm{KO})$, pengaruh religiositas terhadap kepuasan gaji $(\mathrm{R} \rightarrow \mathrm{KG})$, dan pengaruh religiositas terhadap perilaku etis $(R \rightarrow P E)$. Pengaruh positif kepuasan gaji terhadap komitmen organisasional mengindikasikan bahwa seseorang dengan tingkat kepuasan gaji yang tinggi akan menjadikan orang tersebut lebih berkomitmen terhadap organisasinya. Pengaruh positif religiositas terhadap kepuasan gaji dan perilaku etis mengindikasikan bahwa seseorang dengan tingkat religiositas yang tinggi akan lebih puas terhadap gajinya dan akan cenderung berperilaku sesuai dengan etika yang ada.
Salah satu hal yang perlu menjadi perhatian adalah perbandingan besaran koefisien signifikan dari variabelvariabel yang signifikan mempengaruhi perilaku etis yaitu love of money, religiositas, dan komitmen organisasional. Besaran koefisien religiositas $(0,15)$ terhadap perilaku etis lebih besar dibandingkan dengan besaran koefisien love of money $(0,14)$ maupun komitmen organisasional $(0,11)$ terhadap perilaku etis, hal ini mengindikasikan bahwa religiositas memiliki peranan yang lebih besar dalam mempengaruhi kecenderungan seseorang dalam berperilaku sesuai etika dibandingkan dengan love of money maupun komitmen organisasional. Secara keseluruhan, berdasarkan hasil tersebut di atas, H1, H3, H4, H5, H6, dan H8 secara statistik diterima. Sedangkan untuk H2 dan H7 data belum dapat mendukung hipotesis.

Tabel 2 menunjukkan hasil pengujian dan analisis mediasi. Peneliti menggunakan klasifikasi Hair et al. (2017) dalam mengkategorisasikan mediasi. Hair et al. (2017) membagi dua kelompok besar, yaitu nonmediasi dan mediasi; sedangkan nonmediasi terbagi menjadi dua, yaitu direct-only nonmediation dan no-effect nonmediation, sedangkan mediasi terbagi menjadi tiga, yaitu complementary mediation, competitive mediation, dan indirect-only mediation. 
Pada $\mathrm{LOM} \rightarrow \mathrm{KG} \rightarrow \mathrm{KO} \rightarrow \mathrm{PE}$, hubungan mediasi tersebut adalah direct only nonmediation. Hubungan ini diklasifikasikan ke dalam direct only nonmediation dikarenakan love of money memengaruhi signifikan perilaku etis secara langsung (t-value -3,32), namun ketika variabel kepuasan gaji dan komitmen organisasional dimasukkan diantara keduanya, pengaruh tersebut menjadi tidak signifikan ( $t$-value 0,47). Hubungan $\mathrm{R} \rightarrow \mathrm{KG} \rightarrow \mathrm{KO} \rightarrow \mathrm{PE}$ dan $\mathrm{R} \rightarrow \mathrm{KG} \rightarrow \mathrm{KO}$ masuk ke dalam klasifikasi complementary mediation dikarenakan pengaruh langsung maupun tidak langsung menunjukkan hasil yang signifikan dan keduanya memiliki arah yang sama, yaitu positif. Berdasarkan hasil tersebut, maka H10 dan H11 secara statistik diterima, yang berarti pengaruh tidak langsungnya signifikan; sedangkan untuk $\mathrm{H} 9$ data belum dapat mendukung hipotesis.
Penelitian ini memberikan bukti empiris bahwa semakin tinggi kecintaan sesorang akan uang (love of money) dapat menurunkan perilaku etis dari seseorang, karena terlalu mengejar uang dapat berpotensi pada tindakan tidak etis agar dapat memenuhi hasratnya. Hasil penelitian ini sesuai dengan hasil penelitian Tang dan Chiu (2003) yang meneliti pengaruh love of money terhadap perilaku tidak etis pada karyawan di Hong Kong dan penelitian Singhapakdi et al. (2013) yang meneliti pengaruh love of money terhadap intensi perilaku etis pada manajer pemasaran. Hasil penelitian ini menjadi literatur tambahan bahwa pada subjek yang berbeda yaitu karyawan muslim yang bekerja di sektor perbankan ternyata memberikan hasilyang selaras, yakni tingkat love of money yang tinggi akan menurunkan kecenderungan karyawan tersebut berperilaku sesuai etika atau dengan kata lain semakin tinggi tingkat love of money seseorang maka kecenderungan untuk berperilaku tidak etis akan semakin tinggi.

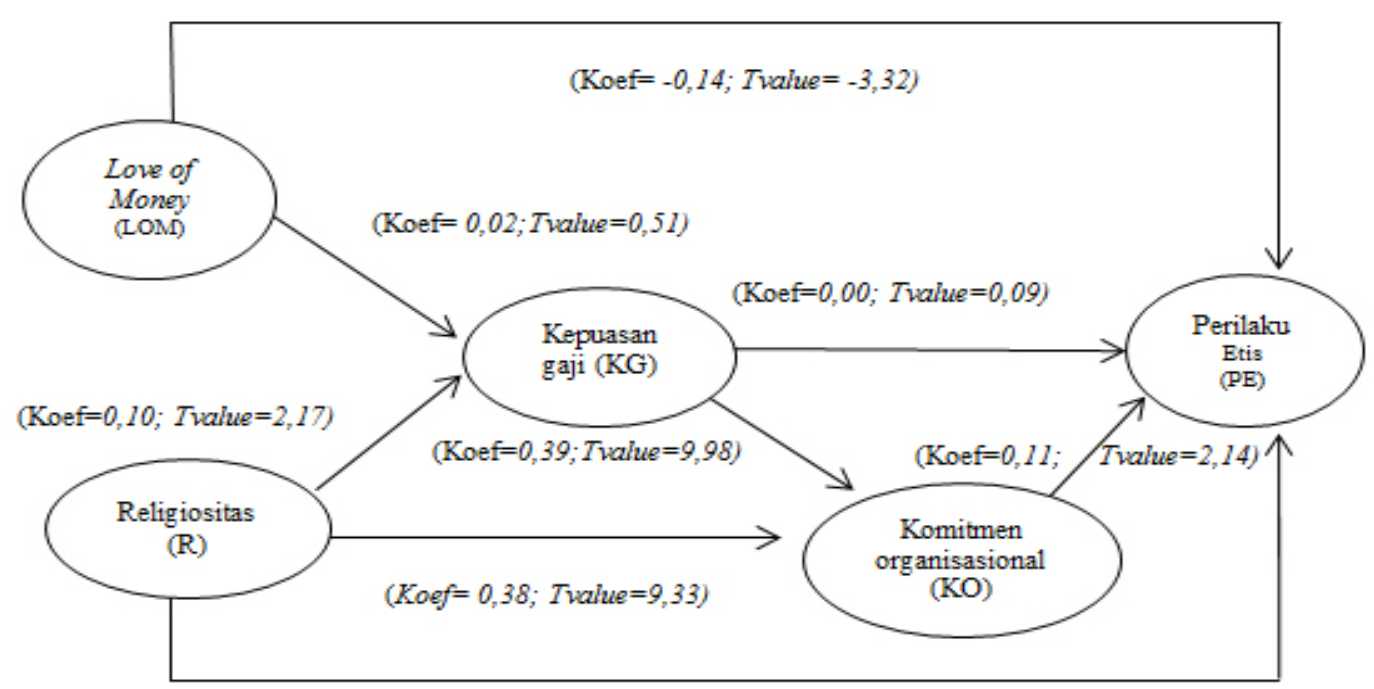

(Koef $=0,15 ;$ Tvalue $=2,98$ )

Gambar 2. Koefisien dan T-value model struktural

Tabel 2. Pengujian mediasi

\begin{tabular}{|c|c|c|c|c|c|}
\hline & $\begin{array}{l}\text { Indirect } \\
\text { effect }\end{array}$ & $\begin{array}{l}\text { T-values } \\
\text { Mediasi }\end{array}$ & $\begin{array}{l}\text { Direct } \\
\text { effect }\end{array}$ & $\begin{array}{l}\text { T-values } \\
\text { langsung }\end{array}$ & Klasifikasi mediasi \\
\hline $\begin{array}{l}\text { Love of money } \rightarrow \text { Kepuasan gaji } \rightarrow \\
\text { Komitmen } \rightarrow \text { Perilaku etis } \\
(\mathrm{LOM} \rightarrow \mathrm{KG} \rightarrow \mathrm{KO} \rightarrow \mathrm{PE})\end{array}$ & 0,00 & 0,47 & $-0,14$ & $-3,32$ & $\begin{array}{l}\text { Direct-only } \\
\text { nonmediation }\end{array}$ \\
\hline $\begin{array}{l}\text { Religiositas } \rightarrow \text { Kepuasan gaji } \rightarrow \\
\text { Komitmen } \rightarrow \text { Perilaku etis } \\
(\mathrm{R} \rightarrow \mathrm{KG} \rightarrow \mathrm{KO} \rightarrow \mathrm{PE})\end{array}$ & 0,05 & 2,29 & 0,15 & 2,98 & $\begin{array}{l}\text { Complementary } \\
\text { mediaton }\end{array}$ \\
\hline $\begin{array}{l}\text { Religiositas } \rightarrow \text { Kepuasan gaji } \rightarrow \\
\text { Komitmen }(\mathrm{R} \rightarrow \mathrm{KG} \rightarrow \mathrm{KO})\end{array}$ & 0,04 & 2,16 & 0,38 & 9,33 & $\begin{array}{l}\text { Complementary } \\
\text { mediaton }\end{array}$ \\
\hline
\end{tabular}


Selain itu pada penelitian ini juga tidak dapat membuktikan keterkaitan love of money terhadap kepuasan gaji, serta kepuasan gaji terhadap perilaku etis. Hasil tersebut berbeda dari studi Tang dan Chiu (2013) yang menemukan bahwa ada keterkaitan antara love of money terhadap kepuasan gaji. Peneliti menduga bahwa perbedaan karakteristik responden dengan penelitian sebelumnya menjadi salah satu penyebabnya terutama berkaitan dengan cara pandang terhadap uang serta nilai yang dianut oleh responden penelitian ini berbeda dengan responden pada penelitian sebelumnya. Berkaitan dengan kepuasan gaji dan perilaku etis, peneliti menemukan bahwa studi yang menguji keterkaitan antara kepuasan gaji dan perilaku etis memiliki hasil yang berbeda-beda. Hasil penelitian ini berbeda dengan hasil penelitian Tang dan Chiu (2003) yang menemukan bahwa seseorang dengan tingkat kepuasan gaji yang rendah akan cenderung berperilaku tidak sesuai etika atau dengan kata lain kepuasan gaji berpengaruh negatif terhadap perilaku etis. Akan tetapi, pada penelitian yang dilakukan oleh Vitell dan Davis (1990) pada profesional bidang manajemen sistem informasi ditemukan bahwa tidak ada hubungan secara langsung antara kepuasan gaji dan pertimbangan etis. Peneliti menduga bahwa pengaruh kepuasan gaji dalam membentuk perilaku etis karyawan perlu dimediasi oleh variabel lain, seperti misalnya komitmen organisasional dalam konteks penelitian ini yang hasilnya juga terbukti.

Jika dilihat dari temuan penelitian, religiositas juga berpengaruh secara langsung terhadap perilaku etis. Semakin seseorang itu memiliki tingkat religiositas yang baik, maka akan dapat mencegah orang tersebut berperilaku tidak etis. Hasil penelitian ini tidak berbeda dengan hasil penelitian yang dilakukan oleh studi lain (de Soto et al. 2018) yang menemukan bahwa seseorang dengan tingkat religiositas yang tinggi akan cenderung memiliki tingkat perilaku etis yang lebih tinggi. Berdasarkan temuan, religiositas juga berpengaruh terhadap terhadap level komitmen seseorang baik secara langsung maupun tidak langsung melalui kepuasan gaji. Hal tersebut mengindikasikan bahwa individu yang memiliki tingkat religiositas yang tinggi akan lebih berkomitmen terhadap organisasinya, Hasil penelitian ini sejalan dengan hasil penelitian Farrukh et al. (2016) yang mengatakan bahwa religiositas berpengaruh signifikan terhadap komitmen secara positif.
Religiositas karyawan juga dapat berpengaruh terhadap komitmen yang bersangkutan terhadap organisasinya melalui kepuasan gaji yang pada akhirnya dapat mencegah seseorang berperilaku tidak etis $(\mathrm{R} \rightarrow \mathrm{KG} \rightarrow \mathrm{KO} \rightarrow \mathrm{PE})$. Hal ini mengindikasikan bahwa tingkat religiositas seseorang dapat menyebabkan individu lebih bersyukur dan merasa bahwa gaji yang dimilikinya cukup memuaskan, ketika karyawan memiliki kepuasan yang baik, karyawan akan merasa lebih berkomitmen dan berupaya tidak melakukan sesuatu yang berpotensi merugikan organisasi melalui tindakannya yang kurang etis. Penelitian mengenai pengaruh religiositas terhadap kepuasan gaji masih sangat jarang, namun hasil penelitian ini tidak bertentangan dengan yang tercantum dalam Alquran surah kedua ayat 172 dan 152 , serta hadis riwayat muslim nomor 7692 tentang perintah untuk bersyukur ketika diberikan rezeki maupun kebahagiaan. Surah kedua ayat 172 berbunyi :"Hai orang-orang yang beriman, makanlah di antara rezeki yang baik-baik yang Kami berikan kepadamu dan bersyukurlah kepada Allah, jika benar-benar hanya kepada-Nya kamu menyembah" (Alquran, 2:172). Surah kedua ayat 152 berbunyi: "Ingatlah kepada-Ku, maka Aku akan mengingat kalian. Bersyukurlah kepada-Ku dan janganlah ingkar" (Alquran, 2:152). Hadis yang mendukung adanya pengaruh religiositas terhadap kepuasan gaji yaitu: "Seorang mukmin itu sangat menakjubkan, karena setiap perkaranya itu baik. Namun, tidak akan terjadi demikian kecuali pada seorang mukmin sejati. Jika ia mendapat kesenangan, ia bersyukur, dan itu baik baginya. Jika ia tertimpa kesusahan, ia bersabar dan itu baik baginya" (HR. Muslim no. 7692, dikutip dalam Purnama, 2017). Dengan demikian, hasil penelitian ini dapat menjadi tambahan literatur dalam membuktikan hubungan pengaruh religiositas Islam terhadap kepuasan gaji yang telah dijelaskan dalam Alquran maupun Hadis.

\section{Implikasi Manajerial}

Penelitian ini memberikan kontribusi pada literatur etika bisnis serta manajemen dan psikologi karena melakukan perluasan pengujian (extension) pada konteks berbeda dari penelitian terdahulu. Penelitian ini juga mengkonfirmasi validitas penggunaan alat ukur love of money serta religiositas Islam pada karakteristik responden yang berbeda. Sedangkan implikasi manajerial terkait hasil penelitian adalah sebagai berikut: 
1. Berdasarkan hasil penelitian diketahui bahwa religiositas memiliki pengaruh langsung yang lebih besar terhadap perilaku etis dibandingkan variabel love of money atau komitmen organisasional. Organisasi dapat menerapkan kebijakan toleransi terhadap ekspresi keagamaan di tempat kerja, karena toleransi ini akan relevan dalam mendorong perilaku etis (Weaver dan Agle, 2002). Toleransi pada ekspresi religiositas seseorang akan memudahkan individu menyesuaikan dengan standar etika agama tersebut.

2. Dalam meningkatkan perilaku etis karyawan, tidak mudah mengubah tingkat religiositas maupun love of money seseorang hanya dengan pelatihan-pelatihan yang disediakan oleh perusahaan. Alternatif terbaik bagi perusahaan untuk meningkatkan perilaku etis karyawannya adalah menjadikan etika sebagai sesuatu yang mengakar di perusahaan dengan cara menjadikan etika tersebut sebagai budaya perusahaan, lama-kelamaan karyawan akan mengikuti budaya etika yang ada di sekelilingnya (Singhapakdi et al. 2013) serta menerapkan aturan dan tindakan tegas terhadap pelanggaran etika.

3. Dari hasil penelitian terbukti bahwa kepuasan gaji dapat mempengaruhi level komitmen pekerja dan berpotensi juga meningkatkan perilaku etis karyawan. Perusahaan dapatmeningkatkankepuasan terhadap gaji dengan cara melakukan kajian internal melalui evaluasi jabatan serta senantiasa memonitor situasi di pasar tenaga kerja melalui survei penggajian, sehingga diharapkan level penggajian yang diberikan minimal dapat setara dengan perusahaan sejenis atau jabatan sejenis sehingga dapat mengurangi potensi kecurangan atau perilaku tidak etis karyawan lainnya di sektor perbankan.

\section{KESIMPULAN DAN SARAN}

\section{Kesimpulan}

Berdasarkan hasil penelitian terbukti bahwa perilaku etis dipengaruhi secara langsung oleh: (1) variabel love of money dan sejalan dengan penelitian sebelumnya (Singhapakdi et al. 2013; Tang dan Chiu, 2003); (2) variabel religiositas yang juga selaras dengan penelitian de Soto et al. (2018). Semakin tinggi hasrat seseorang terhadap uang, maka berpotensi untuk melakukan tindakan kurang etis. Namun, seseorang dengan tingkat religositas yang baik, dalam hal ini berupaya bersungguh-sungguh menerapkan nilai-nilai agamanya yang dalam konteks ini adalah nilai keislaman, dapat berkontribusi terhadap kecendrungan berperilaku etis karyawan tersebut. Religiositas juga memiliki pengaruh tidak langsung terhadap perilaku etis melalui variabel kepuasan gaji dan komitmen organisasional. Sedangkan pengujian pengaruh tidak langsung variabel love of money terhadap perilaku etis melalui variabel perantara, tidak terbukti secara statistik pada penelitian kali ini. Berbeda dari penelitian sebelumnya (Tang dan Chiu, 2003), pada penelitian ini tidak ditemukan adanya keterkaitan variabel love of money terhadap kepuasan gaji, serta kepuasan gaji terhadap perilaku etis.

\section{Saran}

Penelitian ini hanya berfokus pada dua akar penyebab individu dapat berperilaku etis atau tidak (i.e. love of money dan religiositas). Pada penelitian selanjutnya, dapat dipertimbangkan untuk mengikutsertakan faktor lain seperti faktor kepribadian seperti karakter machialiavelianism, karena karakteristik kepribadian ini merupakan salah satu karakteristik kepribadian yang berpotensi menjadi akar beberapa penyimpangan perilaku seperti penipuan atau penyalahgunaan kepercayaan (Tang dan Chen, 2008). Variabel religiositas yang digunakan pada penelitian ini spesifik mengacu pada komitmen religius individu terhadap nilai-nilai keislaman yang dianutnya dan lebih merepresentasikan aspek religiositas internal. Studi di masa yang akan datang dapat mempertimbangkan untuk menguji kedua aspek religiositas baik internal mau pun eksternal (i.e.perilaku religius didasarkan pada motif utilitarian atau alasan egois untuk mencari social approval) terhadap perilaku etis seseorang. Berkaitan dengan alasan situasional pada saat pengumpulan data, peneliti juga menggunakan pengumpulan data survei dengan menggunakan kuesioner hardcopy (4 responden) walaupun dalam jumlah yang sangat sedikit dan sudah dimitigasi secara maksimal, namun ke depannya peneliti tetap menyarankan untuk hanya menggunakan satu saluran utama dalam pengumpulan untuk meminimalisir ketidakkonsistenan hasil survei.

\section{DAFTAR PUSTAKA}

Alam SS, Mohd R, Hisham B. 2011. Is religiosity an important determinant on muslim consumer behaviour in Malaysia? Journal of Islamic Marketing 2(1):83-96.

Alquran dan terjemahannya. 2006. Jakarta: Maghfirah 
Pustaka.

Amaliah I, Aspiranti T, Purnamasari P. 2015. The impact of the values of Islamic religiosity to Islamic job satisfaction in Tasikmalaya West Java, Indonesia, industrial centre. Procedia Social and Behavioral Sciences 211(September): 984-991.

Arli D. 2017. Does ethics need religion? Evaluating the importance of religiosity in consumer ethics. Marketing Intelligence \& Planning 35(2): $205-$ 221.

Association of Certified Fraud Examiners. 2014. Report to the nations on occupational fraud and abuse 2014.

Association of Certified Fraud Examiners. 2016. Report to the nations on occupational fraud and abuse 2016. Association of Certified Fraud Examiners. Retrieved from https://www.acfe.com/rttn2016/ docs/2016-report-to-the-nations.pdf

Association of Certified Fraud Examiners. 2018. Report to the nations on ocuupational fraud and abuse 2018. Retrieved from https://doi. org/10.1002/9781118929773.oth1

de Soto W, Tajalli H, Pino NW, Smith CL. 2018. The effect of college students' religious involvement on their academic ethic. Religion and Education 45(2):190-207.

Farrukh M, Wei Ying C, Ahmed NOA. 2016. Organizational commitment: Does religiosity matter? Cogent Business and Management 3(1):1-11.

Fornell C, Larcker DF. 1981. Structural equation models with unobservable variables and measurement error: Algebra and statistics. Journal of Marketing Research 18(3):382.

Fraedrich JP. 1993. The ethical behavior of retail managers. Journal of Business Ethics 12(3): 207-218.

Hair JF, Black, WC, Babin, BJ, Anderson, RE. 2014. Multivariate data analysis. $7^{\text {th }}$ Ed. Edinburgh: Pearson Education.

Hair, J, Hult, GT, Ringle, C, Sarstedt, M. 2017. A primer on partial least squares structural equation modeling (pls-sem). $2^{\text {nd }}$ Ed. Los Angeles: SAGE Publications, Inc.

Heneman, HG, Schwab, DP. 1985. Pay satisfaction : Its multidimensional nature and measurement . International Journal of Psychology 20: 129141.

Herzog L. 2019. Professional ethics in banking and the logic of "Integrated Situations":
Aligning responsibilities, recognition, and incentives. Journal of Business Ethics 156(2): 531-543.

Joshi V, Goyal KA. 2011. A study of social and ethical issues in banking industry. International Journal of Economics and Research 2(5):49-57.

Kee LB, bin Ahmad R, Abdullah SM. 2016. Relationship between financial compensation and organizational commitment among Malaysian bank workers. Asian Business Research 1(1): 75.

Khraim H. 2010. Measuring religiosity in consumer research from an islamic perspective. Journal of Economic and Administrative Sciences 26(1):52-78.

Mowday RT, Steers RM, Porter LW. 1979. The measurement of organizational commitment. Journal of Vocational Behavior, 247:224-247.

Ogbari ME et al. 2016. Entrepreneurship and business ethics: Implications on corporate performance. International Journal of Economics and Financial Issues 6(3S): 50-58

Otoritas Jasa Keuangan. 2016, November 14. Siaran pers : Tekan kasus tindak pidana perbankan, OJK luncurkan buku "Pahami dan Hindari." Retrieved from https://www.ojk.go.id/id/kanal/perbankan/ berita-dan-kegiatan/siaran-pers/Documents/ Pages/Siaran-Pers-Tekan-Kasus-Tindak-PidanaPerbankan-OJK-Luncurkan-Buku-Pahami-danHindari/siaran-pers-sosialisasi-tipibank.pdf

Paulet E, Parnaudeau M, Relano F. 2015. Banking with ethics: Strategic moves and structural changes of the banking industry in the aftermath of the subprime mortgage crisis. Journal of Business Ethics 131(1):199-207.

Posey C, Roberts TL, Lowry PB. 2015. The impact of organizational commitment on insiders' motivation to protect organizational information assets. Journal of Management Information Systems 32(4): 179-214.

Purnama Y. 2017. Jadilah hamba yang bersyukur. Retrieved from https://muslim.or.id/30031jadilah-hamba-allah-yang-bersyukur.html

Purnamasari P, Amaliah I. 2015. Fraud prevention: Relevance to religiosity and spirituality in the workplace. Procedia-Social and Behavioral Sciences 211: 827-835.

Sardžoska EG, Tang TLP. 2015. Monetary intelligence: Money attitudes - unethical intentions, intrinsic and extrinsic job satisfaction, and coping strategies across public and private sectors in 
Macedonia. Journal of Business Ethics 130(1): 93-115.

Singh P, Twalo T. 2015. Mismanaging unethical behaviour in the workplace. Journal of Applied Business Research 31(2):515-531.

Singhapakdi A et al. 2013. The influence of love of money and religiosity on ethical decisionmaking in marketing. Journal of Business Ethics, 114(1):183-191.

Tang TLP, Chen Y. 2008. Intelligence Vs. Wisdom: The Love of Money, Machiavellianism, and Unethical Behavior across College Major and Gender. Journal of Business Ethics 82(1): 1-26.

Tang TLP, Chiu, RK. 2003. Income, money ethic, pay satisfaction, commitment, and unethical behavior: Is the love of money the root of evil for Hong Kong employees? Journal of Business Ethics 46(1):13-30.

Tang TLP et al. 2018. Monetary Intelligence and Behavioral Economics: The Enron Effect-Love of money, corporate ethical values, Corruption Perceptions Index (CPI), and dishonesty across 31 geopolitical entities. Journal of Business Ethics 148(4): 919-937.

Uyar A, Kuzey C, Güngörmüs AH, Alas R. 2015. Influence of theory, seniority, and religiosity on the ethical awareness of accountants. Social Responsibility Journal 11(3): 590-604

Vitell SJ, Davis DL. 1990. The relationship between ethics and job satisfaction: An empirical investigation. Journal of Business Ethics, 9(6):489-494.

Voegel JA, Pearson J. 2016. Religiosity and ethical ideologies as they pertain to business ethics: Through the lens of the theory of planned behavior. Journal of Leadership, Accountability and Ethics 13(1).

Weaver GR, Agle, BR. 2002. Religiosity and ethical behavior in organizations: A symbolic interactionist perspective. The Academy of Management Review, 27(1):77-97. Retrieved from https://www.jstor.org/stable/4134370

Wening N, Choerudin A. 2015. The influence of religiosity towards organizational commitment, job satisfaction and personal performance. Polish Journal of Management Studies 11(2): 181-191.

Wijanto SH. 2008. Structural equation modelling dengan Lisrel 8.8. Yogyakarta: Graha Ilmu.

Yasin A, Findi M, Hosen MN. 2019. Faktor-faktor yang Memengaruhi Kinerja Pegawai Bank BJB Syariah Cabang Bekasi. Jurnal Aplikasi Bisnis dan Manajemen (JABM) 5(2): 222. 